УДК 631.52.633.63

\title{
ВІДОМИЙ ВЧЕНИЙ-СЕЛЕКЦІОНЕР
}

\section{Г. В. Кулик, науковий співробітник}

Іванівська дослідно-селекційна станщія Інституту иукрових

буряків УАAН

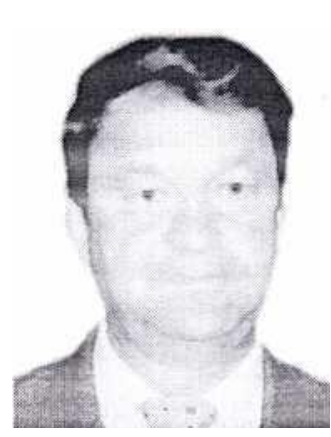

7 січня 2008 року виповнилося 60 років від дня народження відомого селекціонера, кандидата сільсько- господарських наук, заслуженого працівника сільського господарства Лейбовича Анатолія Соломоновича.

закінчення Української сільськогосподарської академії в 1970 р. він розпочав на Іванівській дослідно-селекційній станції, обіймаючи посаду молодшого наукового співробітника, згодом, 31974 р.- старшого наукового

співробітника, і завідувача відділу селекції цукрового буряку.

31977 р. - заступник директора з наукової роботи. Набувши значного практичного досвіду і теоретично обгрунтувавши його, у 1985 р. захистив кандидатську дисертацію.

Лейбович А.С. 3 ентузіазмом розробляв у наукових працях селекційно-генетичні основи створення гетерозисних гібридів на ЧС-основі. Його дослідження зі створення вихідних селекційних матеріалів 3 використанням однонасінності і закріплювальної здатності, самостерильності і самофертильності, стійкості проти хвороб і чоловічої стерильності й нині $є$ перспективними і необхідними для мережі дослідно-селекційних станцій. 
У 1998 р., як висококваліфікований фахівець по селекції, Анатолій Соломонович був призначений директором Іванівської дослідноселекційної станції. Але у 2003 р. за станом здоров'я він змушений був залишити цю посаду. I, будучи завідувачем відділу селекції цукрового буряку, повністю віддався науці.

За роки плідної праці А.С. Лейбович створив цілий ряд нових високопродуктивних гібридів (більше 30-ти), які вивчалися в державному сортовипробуванні, чотири з них: Іванівський ЧС 33, Олександрія, Іванівсько-Веселоподолянський ЧС 84, Ромул занесені до Державного реєстру сортів рослин України. Гібрид цукрових буряків Іванівський ЧС 33, який має високу пластичність, урожайність та цукристість - $€$ національним стандартом.

Його гібриди сьогодні широко впроваджені у виробництво і займають площу близько 100 тис. га.

Йому належать приблизно 30 наукових праць і методичних розробок. Він постійно надає методичну i консультативну допомогу селекціонерам.

Анатолій Соломонович не тільки видатний вчений- селекціонер, але й талановитий педагог, він постійно спілкується з молоддю, піклується про наукову зміну.

Свій ювілей А.С. Лейбович зустрів у розквіті творчих сил, поєднуючи активну наукову діяльність з роботою у вченій раді. Завжди діловий, енергійний, доброзичливий, щедрий на ідеї, він користується беззаперечним авторитетом серед колег і наукової молоді. 


\section{Вимоги до статей}

Науково-практичний журнал “Сортовивчення та охорона прав на сорти рослин” який заснували Державна служба 3 охорони прав на сорти рослин та Український інституг експертизи сортів рослин, публікує теоретичні, аналітичні, узагальнюючі, експериментальні, методичні та практичні статті з актуальних питань сортовивчення та сортознавства за напрямами: теоретичні остови та практичні засади експертизи та державної реєстрації нових сортів рослин;

експертиза нових сортів рослин на вирізняльність, однорідність і стабільність (методологія і процедура проведення); особливості проведення експертизи окремих видів рослин; випробування сортів рослин на придатність до поширення в Україні (методика, критерії та система випробування); методика і процедура перевірки збереженості сортів рослин; правова охорона прав на сорти рослин (розробка принципів та

методів);

формування колекцій сортів-еталонів та використання їх при експертизі нових сортів; забезпечення підтримки та збереженості колекцій сортів рослин;

результати);

ідентифікація зразків сортів рослин (принципи, методи,

вивчення, розробка' та вдосконалення способів i методів сортового контролю посівів;

створення нових та поліпшення існуючих методів контролю за якістю насіння і садивного матеріалу;

міжнародний досвід 3 випробування та охорони сортів рослин; співіснування патентної системи і системи прав селекціонерів; інформаційне забезпечення (інформаційні системи, банки та бази даних, програмування, обмін інформацією тощо);

оглядові статті 3 питань сортових ресурсів рослин та їхнього використання;

інформація (звіти про зарубіжні відрядження, симпозіуми, конференції, урочисті події, персоналії тощо).

Наукові статті мусять відповідати вимогам ВАКу до фахових видань і мати відповідну структуру:

- постановка проблеми у загальному вигляді та ії зв'язок із важливими науковими чи практичними завданнями (науковий рівень Проблеми);

- аналіз останніх досліджень і публікацій, у яких започатковано розв'язання даної проблеми, і на які посилається автор, виділення 
невирішених раніше частин загальної проблеми, котрим присвячується означена стаття (вступ)

- формулювання цілей статті та постановка завдання (тема);

- опис об’єктів і умов проведення досліджень (матеріали і методи досліджень);

- повне обгрунтування отриманих наукових результатів при викладанні основного матеріалу дослідження (результати досліджень та їх обговорення).

За необхідності додається ілюстративний матеріал (таблиці, діаграми, схеми, графіки, рисунки, фотографії), який доводить науковість і достовірність результатів;

- узагальнення результатів досліджень (якісні і кількісні показники здобутих результатів), доцільність їх упровадження в практику та перспективи подальшого розвитку конкретного напряму (висновки та рекомендаціі);

- використана у статті література;

- анотації трьома мовами;

- ключові слова.

Вимоги редакційної колегії до авторів

Редакція запрошує і хоче- бачити у колі своїх дописувачів учених, селекціонерів, дослідників, практиків-агрономів, аспірантів, студентів.

Приймаються статті 3 актуальних питань сортовивчення та охорони прав на сорти рослин теоретичного, аналітичного, узагальнюючого, експериментального, установчого та методичного напрямів за даними не менше двох-трьох років. Дані з урожайності наводяться в т/га.

Статті приймаються у 2-х примірниках українською мовою 3 обов'язковим уживанням букви Гг там, де це потрібно, із супровідним листом від організації або експертним висновком. Додатково додається дискета 3.53 текстом статті. Обсяг статей 8-10 сторінок машинопису, включаючи ілюстрації, таблиці та бібліографію (оглядові статті до 15 сторінок). Остання сторінка тексту 2-го примірника статті має бути підписана автором (авторами).

Текстові файли у форматі редактора Word, WRITE, чорно-білі графічні зображення в любому графічному форматі, шрифт Times New Roman Суг., розмір літер 14, полуторний міжрядковий інтервал, сторінка А4 (210х297 мм), поля по 2 см.

Фотографії (у 2-х примірниках) мають бути розміром 9х12 см, чіткі, контрастні. На зворотній сторінці м’яким олівцем пишеться № фото, автори, назва статті. 
До статті обов'язково додаються анотації (до 5-10 рядків) українською, російською та англійською мовами, ключові слова українською мовою і список використаної літератури.

На окремій сторінці вказується повне ім'я автора (авторів) статті, домашня та службова адреси з контактними телефонами, повна назва місця роботи і посада, вчений ступінь.

На першій сторінці у лівому верхньому куточку вказується індекс УДК. Нижче друкується назва статті ( у заголовках статей наводиться латинська назва культури), під нею прописними літерами

- ініціали та прізвище автора, місце роботи, посада і науковий ступінь.

За зразком, який розташовано у Бюлетені ВАКу України (№ 6, 2007 р. форма 23, С. 12-14), таблиці розміщують після першого посилання на них по тексту у крайньому правому куточку без крапки після номера, назву таблиць наводять жирним шрифтом, назва граф виписується по горизонталі; рисунок підписують: Рис. 1., після назви рисунку ставиться крапка.

При написанні статті посилання на використані першоджерела наводяться в кінці речення (у квадратних дужках). Перелік посилань подається у порядку, за яким вони вперше згадуються в тексті і згідно 3 вимогами ВАКу до бібліографічного опису джерел (бюлетень ВАКу України, № 6, 2007, сторінки 31-33) і національного стандарту України системи СІБВС „Бібліографічний запис. Бібліографічний опис. Загальні вимоги до правил складання”. ДСТУ ГОСТ 7.1-2006. ДСТУ чинний $з$ 7.01.2007р. (К., Держспоживстандарт України, 2007 - 52 с.)

Для перевірки бібліографії статті надавати копію титульного листа чи його звороту з вихідними даними використаного першоджерела.

Одна 3 анотацій російською чи англійською мовою має бути детальнішою, дві інші - ідентичного змісту чіткі і стислі про основні ідеї та висновки статті.

Ключові слова подаються після анотації українською мовою у називному відмінку, підряд у рядку, через кому.

Сподіваємося, що журнал стане вашим помічником і порадником у вирішенні різних проблем з вивчення та впровадження в життя сортів рослин - дуже непростих, цікавих і необхідних об'єктів інтелектуальної власності.

Шеф-редактор,

Член-кор. УААН В. Волкодав 